\title{
The Implementation of Peter the Great's Church Policy in the Eastern Outskirts of the Russian Empire
}

\author{
Irina L. Dameshek ${ }^{1}$ \& Alexandr P. Sannikov ${ }^{2}$
}

Irkutsk State University. Irkutsk, Russia

\begin{abstract}
The church reform of Peter the Great was meant to exercise strict control over the church revenues and expenditures, as well as to heavily regulate parish life. In the outskirts of the empire this is clearly visible in the records of Eastern Siberia which was part of the Irkutsk diocese. Church construction was restricted. The government hoped that a decreasing number of churches would result in less spending by believers and a lessening of the parish clergy. In 1723 the Synod allowed to build new churches, without any special order, only in place of the burned and dilapidated ones, which was followed by a widespread ban on the construction of chapels. Peter the 1st limited the number of the non-pecuniary population, which included the clergy. Censorial (literacy, age) and staff (determined by the number of households in the parish) restrictions were introduced, as well as the system of control over the number of clergy (limiting access to its composition of the pecuniary population). Parish life was also regulated. Parishioners were required to attend temples regularly, to confess and commune, to partake in the Christian sacraments, to attend solemn services announced on various occasions, and to participate in public celebrations requiring attendance in church. In general, the church policy of Peter the Great was clearly aimed at gaining control over the process of church building, restraining the growth of the parish clergy, and formalizing parish life. The Synod became the organizer of this policy, and the episcopate became the guide.
\end{abstract}

\section{Keywords}

Peter The Great; Synod; Orthodox Church; Episcopate; Eastern Siberia; Irkutsk Diocese; Clergy; Church Policy; Parish Life; Church Building

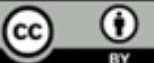

This work is licensed under a Creative Commons "Attribution" 4.0 International License

1 Email: dameshek[at]rambler.ru

2 Email: aps.72[at]mail.ru 


\title{
Реализация церковной политики Петра I на восточных окраинах Российского государства
}

\author{
Дамешек Ирина Львовна ${ }^{1}$, Санников Александр Павлович ${ }^{2}$
}

Иркутский государственный университет. Иркутск, Россия

\section{Аннотация}

Церковная реформа Петра I имела целью жесткий контроль над церковными доходами и расходами, а также неукоснительную регламентацию приходской жизни. На окраинах империи это четко прослеживается по материалам Восточной Сибири, входившей в состав Иркутской епархии. Было ограничено церковное строительство. Правительство надеялось, что уменьшение числа церквей повлечёт снижение расходов верующих и сокращение приходского духовенства. В официальных документах начала XVIII в. практически не встречается ни одного указа по вопросу выделения денежных средств на строительство приходской церкви. В 1723 г. Синод разрешил без особого своего распоряжения строить новые церкви лишь вместо сгоревших и обветшалых, затем последовал повсеместный запрет на строительство часовен. Епископату предписывалось изменить границы приходов. Цель: ликвидировать малые приходы и не допускать их возникновения впредь. Петр I ограничил численность неподатного населения, в состав которого входило духовенство. Вводились цензовые (грамотность, возраст) и штатные ограничения (определялось по количеству дворов в приходе), система контроля над численностью духовенства (ограничение допуска в его состав податного населения). Регламентации подверглась и приходская жизнь. От прихожан требовали регулярного посещения храмов, обязательной исповеди и причастия, приобщение к христианским таинствам, посещение торжественных богослужений, объявляемых по различным случаям, участие в государственных праздниках, требующих присутствия в церкви. В целом, церковная политика Петра I имела четкую направленность на установление контроля над процессом церковного строительства, сдерживание роста приходского духовенства, формализацию приходской жизни. Организатором этой политики становится Синод, а проводником выступает епископат.

\section{Ключевые слова}

Петр I; Синод; Православная церковь; епископат; Восточная Сибирь; Иркутская епархия; духовенство; церковная политика; приходская жизнь; церковное строительство

Это произведение доступно по лицензии Creative Commons “Attribution” («Атрибуция») 4.0 Всемирная

1 Email: dameshek[at]rambler.ru

2 Email: aps.72[at]mail.ru 


\section{Введение}

Конфессиональная составляющая являлась одним из факторов, определявших государственно-правовое развитие окраин Российской империи. Распространение православия на территории Восточной Сибири началось в 30-е годы XVII в. одновременно с появлением первых русских поселенцев. Процесс структурного формирования институтов русской православной церкви представлял собой сложное и продолжительное явление в общественной жизни региона, включавший в себя строительство культовых сооружений и их обеспечение, образование общинно-приходской организации, формирование приходского духовенства, развитие устойчивой системы церковно-административного управления. Огромное влияние на этот процесс оказывали два фактора - темпы русской колонизации и церковная политика правительства. Рассмотрению ключевых элементов этой политики в эпоху Петра I и их реализации на практике посвящена данная статья.

Со времен основания Московского государства взаимоотношения церкви и государства определялись как «симфония властей». В основе этой доктрины лежала идея гармонии и согласия церкви и государства, своеобразной «духовной симфонии», при которых каждая из ветвей поддерживала другую, образуя мощный и устойчивый союз. Эта идея была заимствована из Византии. Она успешно реализовывалась в XVII в. как в центральной части российского государства, так и на его окраинах, в частности, в Восточной Сибири. Итогом реализации этой политики стало строительство в крае первых часовен, церквей, монастырей и учреждение Тобольской и Сибирской архиепископии (впоследствии митрополии).

Отказ от данной доктрины произошел в период правления Петра I. Властям стал нужен не союзник, а исполнитель, проводник общегосударственной имперской политики. Это предопределило шаги правительства по церковному вопросу.

Ключевыми элементами новой политики стали: контроль и реорганизация строительства православных храмов, запрет на часовенное строительство, реорганизация прихода, контроль и ограничение численности приходского духовенства, регламентация приходской жизни.

Курс, определенный Петром I, продолжали его преемники. Реализация мер правительства осуществлялась Сенатом и Синодом, как органами государственного управления. На местах в жизнь эти мероприятия проводили гражданская администрация и епархиальные архиереи. Как этот процесс происходил на восточных окраинах российского государства, можно наглядно проследить по материалам Восточной Сибири, входившей в состав Иркутской епархии. 


\section{Церковное строительство и его регламентация}

Одним из первых вопросов, внесенных в повестку дня правительством, стал вопрос о строительстве церквей. Среди сподвижников Петра I возобладало мнение, что ограничение или уменьшение числа церквей приведет к сокращению финансовых и трудовых затрат верующих, сохранению материальных ресурсов и сокращению неподатного элемента - приходского духовенства. Для осуществления этой идеи правительство разработало ряд мер.

Первым шагом такой политики стал фактический отказ от прямого финансирования церковного строительства в государстве в целом и Восточной Сибири в частности. Ранее при назначении воевод в сибирские городки им выдавались наказы с требованием обеспечить возведение церквей и монастырей. Например, якутскому воеводе Головину в 1638 г. предписывалось устроить в остроге церковь (Санников, 2016, с. 80). В 1709 г. радением якутского воеводы Якова Елчина на берегу Лены в 80-ти верстах выше Якутска была построена Покровская пустынь с церковью во имя Покрова Пресвятой Богородицы. В Иркутске при деятельном участии приказчика сына боярского Ивана Максимова, пятидесятника Анисима Михалева и десятника Ивана Турчанинова в 1672 г. организовано строительство Вознесенского монастыря (Санников, 2016, с. 159).

В официальных документах начала XVIII в. мы практически не видим ни одного указания по вопросу выделения денежных средств на строительство приходских церквей. Мирские челобитные о материальной помощи со стороны государства получали отказ или оставались без ответа. Правительство предпочитало, чтобы крестьяне сами строили церковь и несли расходы по ее обеспечению (Зольникова, 1990, с. 64).

Другой мерой правительства стало ограничение на использование ряда материала при постройке церкви. После поражения под Нарвой, когда русская армия потеряла почти всю артиллерию, Петр I 4 февраля 1701 г. издал указ о переплавке части колоколов «в городах у соборных и приходских церквей, архиерейских и боярских домах, монастырях, вотчинных селах» на пушки. Медь и олово также направлялись на военные нужды. Литье колоколов на некоторое время приостановилось. Запрещалось также выделять и использовать «добрый» лес, годный к корабельному строению (Санников, 2016, с. 85). В Сибири данная мера правительства в ряде мест стала трактоваться как ограничение на порубку леса для строительства храмов (Санников, 2016, с. 85). Потребовалось дополнительное разъяснение, поступившее в 1751 г., предписывавшее:

«Не чинить препятствий в порубке леса в Сибири на построение церквей» (Щеглов, 1993, с. 159). 
Самые радикальные шаги по ограничению церковного строительства власти предприняли в 1722 г. 31 октября 1722 г. вышло синодальное определение, предписывавшее:

«...всем архиереям и прочим чинам объявить и письменно подтвердить, чтоб как архиереи, так и по монастырям и прочим местам церквей, где наперед не бывало или хотя и бывало, но за умалением прихода и за скудостию потребных и за другими неудобствами быть не у чего: вновь без указания Синода не делали» (Санников, 2016, с. 52).

Объяснялось подобное решение тем, что возникло «небрежение славе божией в лишних церквях и в множестве попов» (Санников, 2016, с. 53).

Для того, чтобы приступить к постройке храма, требовалось доставить челобитную или прошение в Синод (ПСПиР, 1875, №1134). Составить ее требовалось по особой форме с указанием: «На каком месте и на чьей земле каменную или деревянную церковь построить кто желает, и во чье имя, и какая нужда к тому новой церкви строению ведет, и чем он будет священнослужителей довольствовать, и откуда оная церковь по всегдашнему священнослужению потребное получать будет, и какое на то положит он утверждение, и не сумнительная ли в том будет надежда, и при коликах какого звания приходских дворах быть имеет, и те дворы до того времени в которых приходах и в коликом разстоянии от онаго места обретаются» (ПСПиР, 1875, №1134).

За достоверность представленных сведений отвечал архиерей, который обязывался «изследование с достоверным свидетельством правдиво чинить». Челобитчикам предписывалось «ожидать решительных из Синода указов, никому церковного строения не позволять и не строить, под тяжким штрафованием». Указ не делал никакого исключения и для сгоревших церквей:

«В которых местах построены издавна деревянные церкви от огненного запаления сгорят, требователям чинить как выше сего изображено» (ПС3-1, 1830, T.VI, №4122).

В 1723 г. Синод несколько смягчил положения этого указа: разрешалось строить новые церкви вместо сгоревших и обветшалых, «таких, которые были обложены данью, занесенною в табельный оклад» (ПСПиР, 1875, №1054). При этом доклада в Синод или особого его распоряжения не требовалось. Считалось достаточным наличие решения архиерея (Санников, 2016, с. 54). Однако данное решение не удовлетворило большинство архиереев, которые продолжили оказывать давление на власти (Санников, 2016, с. 59).

Своеобразной победой епископата можно считать указ Екатерины I от 22 декабря 1726 г. В нем повелевалось

«как в Синодальной области, так и во всех епархиях всяких чинов людям, ежели пожелают, где прежде были и вновь строить каменные и деревянные церкви, и таковым желающим, о том строении подавать прошении своей Синодальной области в духовной дикастерии, а в епархиях архиереям, в которых велеть им 
все обстоятельства, для чего где церковь построить надлежит, писать именно без всякого упущения и принимая те, чинить свидетельства самою сущею правдою без всякого пристрастия, вероятия достойными персонами; и по тому свидетельству разсматривать дикастерии заседающим членам, а в епархиях архиереям» (ПСЗ-1, 1830, T.VII, №4988).

Тем самым контроль над церковным строительством вновь возвращался в руки епископата, однако сохранялись требование «излишних церквей не строить».

Окончательное решение вопроса о церковном строительстве состоялось при Екатерине II. 10 декабря 1770 г. Синод опубликовал определение, предписывавшее:

1. Епархиальным архиереям разрешить санкционировать строительство церквей на месте сгоревших или обветшавших без дополнительного указания Синода.

2. На строительство церкви на новом месте просить разрешение Синода. Без решения Синода строить новые церкви запрещалось (ПС3-1, 1830, T.XIX, №13541).

Таким образом, к концу XVIII в. правительство вновь вернулось к политике времен Петра I и возобновило контроль над церковным строительством.

В 1723 г. Синод принял еще одно решение, предписывавшее церкви «строить только в деревнях, находящихся в дальнем разстоянии от существующих церквей... и имеющих от 60 до 80 дворов» (ПСПиР, 1875, №1054). В Иркутской епархии найти село, имевшее в это время от 60 до 80 дворов, было трудно. Указ стал сдерживающим фактором в ходе церковного строительства. 25 ноября 1757 г. последовало дополнение к указу 1723 г.: архиерей мог разрешить строить церковь лишь в том случае, когда от селений до старой церкви расстояние было больше 20 верст (ПСЗ-1, 1830, T.XIV, №10780).

В 1778 г. своеобразным ходатаем от Сибири выступил тобольский губернатор Д.И. Чичерин. В своем обращении к Синоду он указывал:

«...в Тобольской губернии по великой обшироности оной и безчисленного множества пустых земель, лежащих в отдалении от прежденаселенных жилищ, по именным указам приведенными из России посельщиками больше 40 тысяч душ мужеска пола заселено великими слободами, разстоянием от церквей от 150 до 300 верст, чем претерпевая великую нужду, неотступно просят о построении своим коштом церквей, но как без докладу Синоду Преосвященный тобольский о строении вновь церквей дозволения дать не может, а между тем время продолжается в их терпении», то не даст ли Синод указ тобольскому архиерею самому разрешать строить новые церкви «по представлениям к нему от него, господина губернатора» (Зольникова, 1990, с. 121).

19 сентября 1778г. Синод удовлетворил просьбу губернатора. Действие указа было распространено и на Иркутскую епархию. 
Если по вопросу церковного строительства гражданским и церковным властям Сибири удалось найти взаимоприемлемые решения, то по отношению к часовням правительство в начале XVIII в. заняло более жесткую позицию и практически не сделало уступок.

25 ноября 1707 г. именным указом монарха строительство часовен повсеместно было запрещено. В историографии подобный шаг правительства объясняется по-разному. По мнению Н.Н. Покровского, «при часовнях формировалась особая форма крестьянского религиозного сознания, крестьянский вариант православия, существенно не совпадавший с официальным православием» (Покровский, 1979, сс. 55-57). Н.Д. Зольникова основную причину видит в борьбе с расколом: «Надзор за православными часовнями, часто раскиданными по глухим деревням, был куда более трудным, чем за церквями. Нередко в часовнях тайно отправляли богослужение старообрядцы беспоповских согласий» (Зольникова, 1990, с. 140). Нельзя не заметить и стремление правительства затормозить ход церковного строительства, так как часовни не редко перестраивалась в церковь, путем прируба алтаря.

28 марта 1722 г. Синод принял еще более радикальное решение «о разобрании всех существующих часовен и нестроении впредь новых». Объяснение давалось простое:

«в городах и селах обретается и кроме часовен довольно церквей для славословия божьего имени правильно созданных и посвященных» (Описание..., 1879, №422).

Указ был разослан по всем епархиям и немедленно вступил в силу. По всей империи начался так называемый «часовенный разбор». Из часовен выносились иконы, предметы культа, снимались колокола, описывалась казна, а сами часовни разбирались, забивались или передавались частным лицам под хозяйственное использование.

«Часовенный разбор» продолжался почти 5 лет. 5 мая 1727 г. Синод разрешил возобновить моления в неразрушенных еще часовнях и восстанавливать старые, при наличии ходатайств. Архиереям при этом указывалось

«...разсматривать прилежно, чтобы не было правильного препятствия и раскольникам какого способу, а святым церквам обиды и уничижения» (ПСПиР, 1881, №1959).

В 1728 г. это решение подтвердил своим указом Петр II. «Часовенный разбор» на некоторое время удалось прекратить и начать их восстановление. Но отступление правительства оказалось временным, вскоре Синод вернулся к законодательству времен Петра I. 10 июня 1734 г. последовало определение: старые часовни оставить в «прежнем состоянии», а новых не строить. Запрет касался также восстановления ветхих или сгоревших. Расчет делался на то, что часовни прекратят свое существование по ветхости или от пожара. 
В документах XVII-XVIII вв. в Восточной Сибири упоминаются более 50 часовен. Поскольку учет часовен не велся, можно предположить, что их число было сопоставимым с количеством церквей, т.е. в пределах 80-90. Практически ежегодно в регионе воздвигалось несколько часовен, зачастую без разрешительных грамот. В соборных статьях 1703 г. отмечалось:

«Ведомо нам великому господину учинилось, что в низовых городех многие часовни построены без архиерейского благословения и грамот» (Древние церковные грамоты, 1875, с. 135).

Тобольский митрополит Филофей (Лещинский) предписал Даурскому заказчику архимандриту Селенгинского Троицкого монастыря Мисаилу:

«Тебе архимандриту без нашего архиерейского указу в городех и в селех и в деревнях церквей и часовен строить отнюдь не велеть, а велеть о том бить челом нам великому господину» (Древние церковные грамоты, 1875, с. 134).

Вновь построенные часовни приписывались к близлежащим приходским церквям.

Тобольский митрополит Антоний (Стаховский) предпринял попытку остановить ход «часовенного разбора» в Сибири. 20 января 1723 г. он направил в Синод прошение, в котором указывал, что много часовен построено для «новокрещенных инородцев», просивших их не разбирать. Решение Синода не заставило себя долго ждать: в 1724 г. поступил ответ: «...воспрещается возобновлять их у инородцев в Тобольской епархии» (ПСПиР, 1876, №1393). При этом предписывалось строить на их месте церкви, взяв с инородцев «крепкое обязательство» о содержании церквей и духовенства.

Не получив поддержки Синода, митрополит Антоний (Стаховский) приступил к «запечатыванию» часовен. Началось изъятие часовенной казны, передача в близлежащие церкви икон, колоколов, утвари и предметов культа, снятие с крыши креста или головки. Примером «запечатывания» может служить судьба Кежемской Николаевской часовни. Ее построили в начале XVIII в. крестьяне Кежемской слободы во имя Св. Николая и приписали к Богоявленской церкви Братского острога. В 1723 г. священнику этой церкви Никифору Иванову поступило предписание «запечатать» Николаевскую часовню. 1 апреля он прибыл на место. В ходе закрытия часовни было изъято 15 икон, все предметы культа, 2 колокола, 9 книг и 25 рублей из часовенной казны. После «запечатывания» богослужения в часовне не проводились 5 лет. В 1728 г. часовню восстановили, и богослужения в ней продолжились. В конце 1734 г. жители узнали о новом указе и 14 марта 1735 г. обратились к иркутскому епископу Иннокентию (Неруновичу) с прошением «чтоб прирубить к часовне олтарь и освятить ее в церковь и дозволить им сделать збор на заведение колоколов» (ИЕВ, 1870, с. 530). Благословение было получено, и уже в июле 1737 г. большеокинский священник Стефан Шергин и иеродьякон Дометиан освятили новую Кежемскую Николаевскую церковь. 
Иногда «запечатывание» встречало сопротивление со стороны верующих. В Тункинском остроге оно едва не переросло в вооруженное противостояние. Часовню в этом остроге построили казаки, прирубив при строительстве укрепления к острожной стене еще три. Поводом для ее возведения стало «явление» иконы св. Николая. Данная икона особо почиталась не только русскими поселенцами, но и бурятским населением. В 1723 г. для упразднения Николаевской часовни в Тунку прибыли священник Василий Канаровский и казачий командир Черепанов. В остроге ударили в набат, прихожане и инородцы не допустили прибывших к часовне. Ни угрозы Черепанова, ни уговоры священника ни к чему не привели. Командир, оскорбившись непослушанием, снял саблю и бросил ее на землю. Верующие устояли и не позволили тронуть часовни (ИЕВ, 1880, сс. 534-540).

Пик закрытия часовен в регионе пришелся на 1723 г. В 1724-1725 гг. «запечатывания» продолжились, но они уже не носили столь массового характера. В его ходе в Иркутской епархии было закрыто или перестало существовать более 40 часовен.

Восстановление часовен началось в 1727 г. Это вызвало эйфорию в сибирском обществе. Зачастую сами прихожане восстанавливали свою часовню, без распоряжения епископа, ссылаясь на «государев указ». Другие прихожане стали обращаться к приходским священникам за разрешением о «возобновлении часовни». Иркутский епископ Иннокентий (Кульчицкий) вынужден был принимать жесткие решения. Когда прихожане Идинской Троицкой церкви уговорили священника Григория Смагина открыть две часовни, в Бейтоновской заимке и Евсевьевской деревне епископ приказал часовни закрыть, а священника выпороть плетьми (ИЕВ, 1864, с. 452).

Указ 1734 г. поставил епархиальные власти в двойственное положение: они должны были исполнять решение вышестоящего органа - Синода и поддерживать религиозные чувства прихожан. Особенности региона также накладывали свой отпечаток. В ходе разлива рек и плохого состояния дорог многие верующие оказывались отрезанными от приходского храма. Это заставляло крестьян просить о построении часовни. Церковные власти просто вывели часовни из-под учета и не упоминали о них в официальных документах.

Наиболее типичную картину видно из донесения заказчика тобольской митрополии Ф. Знаменского за 1744 г.:

«...чесовни вновь строят самовольно, но токмо креста вверху не воодружают, а имеюще их в молитвенные храмы в разные праздненства празднуют, а при других чесовнях и мертвых погребают, у которых чесовен збираетца денежная казнасвоим самоволством, а не вашим архипастырским благоволением... А наипаче выборные старосты при оных чесовнях сами собою зборную казну изнуряют» (Зольникова, 1990, с. 142). 


\section{Ограничительная политика в отношении приходского духовенства}

Петр I также решительно приступил к ограничению численности неподатного населения, в состав которого входило духовенство. Вводились цензовые и штатные ограничения, а также система контроля над численностью духовенства.

Первым стал ценз грамотности. Все церковные служители должны были уметь читать, писать, вести делопроизводственные документы. 15 января 1708 г. Петр I подписал указ об обязательном обучении поповских и дьяконских детей. Предусматривалось создание школ для детей духовенства. При этом определялось:

«которые учиться в оных школах не пожелают на отцовские места не ставить и не принимать их ни в какие чины, кроме воинской службы» (ПС3-1, 1830, T.IV, №2186).

11 ноября 1710 г. вышел еще один указ, предписывавший духовенству обучать своих детей грамоте. Не пожелавших учиться требовалось «обучать насильно» или записывать в солдаты (ПС3-1, 1830, T.IV, №2308). Лицам, не имевшим образования, доступ в духовное сословие закрывался.

Вскоре этот ценз научились обходить. Главным было умение читать, писать и иметь навыки богослужения. Остальное делалось при помощи даров служителям архиерейского приказа (Посошков, 1951, с. 29). По замечанию И.Т. Посошков, «архиерейские служители у новопоставленников приемлют дары и, приняв дары, дадут ему затвердить по псалтыри некоторые псалмы и, заложа, дадут перед архиереем тому ставленнику прочести. И, архиерей, видя его твердо и разумно читающа псалтырь, возмнит, якобы и во всяком чтении таков, благословит его во презвитерство. И тако те служители архиереев своих в порок приводят» (Посошков, 1951, с. 30).

Со взяточничеством иркутские епископы пытались бороться. В 1733 г. епископ Иннокентий (Нерунович) наложил «урок смирения» на главу архиерейского приказа игумена Вознесенского монастыря Паисия (Давыдова), уличенного во взяточничестве, приказав его публично выпороть (Наумова, 1996, с. 53).

В дальнейшем последовало введение возрастного ценза. 25 апреля 1711 г. правительство определило: «Кто 25 лет не имеет дьякон да не будет и священник не бывает, аще 30 лет не имать» (ПС3-1, 1830, T.IV, №2352).

Логическим завершением мероприятий правительства стало введение в 1722 г. церковных штатов. Штатная численность приходского духовенства определялось по количеству дворов в приходе. 


\begin{tabular}{lccccc}
\hline \multirow{2}{*}{ Число дворов } & \multicolumn{5}{c}{ Полагалось иметь: } \\
\cline { 2 - 5 } & Священников & дьяконов & дьячков & пономарей & \\
\hline 100 и более & 1 & - & 1 & 1 & 3 \\
200 и более & 2 & 1 & 2 & 2 & 7 \\
300 & 3 & 2 & 3 & 3 & 11 \\
\hline
\end{tabular}

Таблица 1. Штатная численность приходского духовенства (Описание..., 1879, №756).

Table 1: Staff numbers of parish clergy (Description..., 1879, no. 756).

Посвящение в духовный сан регламентировалось. Указом от 30 ноября 1705 г. каждый кандидат до посвящения должен был представить епархиальному архиерею: прошение о посвящении, выбор прихожан, справку из архиерейского приказа о социальном и податном положении просителя, его возрасте, грамотности, а также донесение заказчика со сведениями о наличии вакантных мест и достоверности сведений, представленных просителем. Вся ответственность за организацию ставленнического дела возлагалась на архиерея. При посвящении в сан лиц из податного населения он нес ответственность перед Синодом.

Еще одним шагом правительства, направленным на сдерживание численности приходского духовенства, стало ограничение допуска в его состав представителей податного населения. В 1722 г. Синод подготовил определение, в котором епархиальным властям предоставлялось право производства в духовные чины представителей податного населения только при согласии общины платить подушный оклад за выбывшего и письменного отпуска от светской команды (Зольникова, 1977, с.18).

В указе Сената от 2 июля 1744 г. правительство еще более ужесточило свою позицию:

«священнослужителей с детьми, родившимися после принятия сана, из оклада исключить, а их детей, рожденных до священства, а также церковников с детьми отчислить из духовного сословия и отправить на прежние места, где они были зачислены в оклад» (ПСЗ-1, 1830, T.XII, №8981).

Для исполнения этих положений правительство организовало «разборы» излишнего духовенства. «Разбор» предусматривал отчисление излишнего приходского духовенства, с зачислением в податные или солдаты. Под разбор попадали:
а) внештатные («излишние») священнослужители и причетники,
б) отставные служители церкви, кроме священнослужителей,
в) «сироты», лица, не имевшие живых родственников и определенные для пропитания к служению при церкви,
г) неграмотные церковнослужители, 
д) представители податного населения, определенные на церковные места без соответствующей отписки из своей «команды» или оказавшиеся в «прописке»,

е) дети, родившиеся до получения духовного сана родителями и родственники (племянники, братья, «дядья») священнослужителей.

Первый из «разборов» был проведен властями по мере введения церковных штатов в 1722-1724 гг. Последующие проводились, как правило, по итогам ревизий или назначались по особому решению Сената и Синода. В течение XVIII в. разборы проходили в 1737 г., 1744 г., 1755 г., 1769 г., 1784 г. Действенность «разборов» должно было усилить участие в них гражданских властей.

В Сибири первый разбор 1722-1724 гг. оказал незначительное влияние и носил скорее организационный характер. В ходе него было четко определено количество вакантных мест и произведено выделение непрямых родственников (племянников, «дядьев» и проч.) из состава духовной «команды». Каких-либо кадровых потерь духовное сословие не понесло.

Самым тяжелым из них оказался «разбор» 1737 г. В отличие от предыдущего, он строго контролировался правительством императрицы Анны и проводился под личным надзором Феофана Прокоповича. Перед его началом был проведен расчет «необходимого» для служения духовенства. Он предусматривал наличие 4 клириков на 1 приходскую церковь, на которых полагалось иметь 8 женщин, в разных комбинациях (жена, дочь, теща и т.д.) и 8 детей (по 2 чел. не положенных в оклад). В целом на 1 церковь определялось иметь не более 20 лиц, относившихся к духовному сословию. Всего к 1737 г. в России насчитывалось 18.000 церквей. Следовательно, в составе приходского духовенства должно было остаться не более 360.000 чел. Однако в это время, согласно правительственным данным, в Российской империи проживало 150.000 семей приходского духовенства, что при самых скромных подсчетах (3 члена семьи) составляло более 480.000 чел. Таким образом, более 120.000 чел. обрекалось на «разбор» и исключение из состава духовного сословия (Карташев, 1992, сс. 527-528). Гражданским властям, осуществлявшим «разбор», не возбранялось «перевыполнять норму».

«Разбор» проводился жестко по всей России, не стала исключением и Иркутская епархия. По региону прокатилась волна отстранений от должностей, большей частью пострадали причетники. Так, в Усть-Кутском остроге власти отстранили от служения дьячка Василия Косыгина. Основанием стало происхождение из семьи плотника. В Яндинском остроге, также по причине происхождения, был арестован священник Аврамий Белых. Во время разбирательства о его происхождении он «повредился в уме», начал называть себя Христом, царем, патриархом и римским папою и грозил, что всех начнет судить. По решению епископа больного поместили в Вознесенский монастырь. В Иркутске поручик Адриан Греченин подошел к Прокопьевской церкви 
с солдатами и после богослужения арестовал дьякона Онисифора Бобровникова и поместил на съезжую. Причиной ареста также явилось происхождение. Он родился до того, как его отец, Козьма Бобровников, был рукоположен в священника, поэтому оказался приписанным в состав посадского населения Балаганска и впоследствии не был из него исключен, т.е. оказался в «прописке». Дьякона не только «удалили от церкви», но и потребовали немедленно заплатить подушный оклад за прошедшие 10 лет. Только после личного вмешательства епископа и вице-губернатора Плещеева Онисифор Бобровников был освобожден и восстановлен в церковной должности (ИЕВ, 1868 , с. 12$)$.

Если бы «разбор» в Иркутской епархии был проведен с соблюдением всех требований, то половина церквей вообще лишилась бы причетников и около трети могли остаться без священнослужителей. Иркутский епископ Иннокентий (Нерунович) занял решительную позицию по защите интересов приходского духовенства. Он неоднократно обращался с прошениями в Синод, Сенат и императрице, как мог, защищал каждого церковнослужителя, не боялся идти на конфликт с гражданскими властями, что требовало огромного мужества и смелости, учитывая времена «бироновщины». Во время поездки в Якутск епископу удалось освободить более 15 сыновей священнослужителей, которых местный воевода уже определил в солдаты (Наумова, 1996, c. 51).

В своем донесении в Синод епископ Иннокентий (Нерунович) указывал: «Епархия Иркутская есть весьма малая и скудная в которой к настоящим церквям в священники выбирать не из кого, також и в причетники, аще бы не было приезжих людей из иных епархий. А которые священнические и причетнические дети малое число при мне в школе и обучаются, но еще весьма малые и в такие достоинства производить их невозможно, а в епархии моей великое в священниках оскудение и в причетниках» (НАРТ, ф. 10, оп. 2, д. 899, л. 359).

В 1739 г. Синод вышел с ходатайством в Сенат «о дозволении посвящать в духовные чины Иркутской епархии податных людей». Сенат согласился с предложением Синода, при этом не только разрешил посвящать в сан податных людей, но и освободил их «от всех служб и податей, которые они несли в гражданской команде» (Зольникова, 1990, С.95). Иркутская епархия стала единственной, для которой было сделано подобное исключение.

Во время разбора 1769 г. иркутскому губернатору Брилю предписывалось осмотреть годных к военной службе сыновей церковников, что было связано с очередной русско-турецкой войной. Отмечалось, что в среде духовенства много таких, которые

«за их празностию ... ни в подушный оклад никуда не записывались, ниже в семинарское учение доныне никуда не вступали и принадлежащими науками священническому чину достойному себя не зделали» (Шерстобоев, 1957, с. 560). 
Губернатору предписывалось взять на военную службу четвертую часть всех лиц в возрасте от 15 до 40 лет и половину дьячков, пономарей, сторожей, «отставленных», неграмотных и недоучившихся. Узнав об этом большинство клириков «сказались больными» или просто подались в бега. В солдаты удалось взять 7 чел. из Илимского заказа и 8 чел. - из Иркутского (Шерстобоев, 1957, с. 560).

\section{Регламентация приходской жизни}

Другим шагом правительства стала регламентация приходской организации. Епископату предписывалось изменить границы приходов,

«чтоб довольное число ко всякой церкви прихожан было приписано, чтоб от подаяния прихожан весь причт мог иметь довольный трактамент» (ИЕВ, 1864, c. 472$)$.

Преследовалась цель ликвидировать малые приходы и не допускать их возникновения впредь.

В Сибири реорганизация началась в 1723 г. В мае того года состоялась перепись всех населенных мест и закрепление их за приходскими церквями. Итогом данного мероприятия стало фактическое прикрепление верующих к церкви (Санников, 2010, с. 269).

В эпоху Петра I не осталась без внимания правительства и приходская жизнь. Власти требовали от прихожан регулярного посещения храмов, обязательной исповеди и причастия, приобщение к христианским таинствам, посещение торжественных богослужений, объявляемых по различным случаям, участие в государственных праздниках требующих присутствия в церкви.

Посещения церкви в начале XVIII в. в Иркутской епархии были регулярными. Прихожане предпринимали меры, «дабы не лишатися службы и протчих церковных таин». Женщины посещали приходскую церковь чаще, чем мужчины. Так, жители Балейской деревни в своем прошении «о возобновлении часовни» писали:

«... тоя балейской деревни жители обретаемся мы в приходе Усольской слободе чему свидетельствует тоя слободы священник Иван Марков что мы за дальностию от церкви для моления соборнаго желаем часовню вновь построить а церкви святой никакой обиды и уничижения не будет понеже мы в праздники и в воскресные дни к церкви будем для моления» (ГАИО, ф. 50, оп. 1, д. 3, л. 197).

Во второй половине XVIII в. посещения церквей становятся уже не столь регулярными. Верующими выдвигались разные причины: «не имеется одежды и обуви», «за дальностию и одиночеству» и др. К тому же воскресный день зачастую совпадал с «базарным днем» и перед мужчинами стоял выбор куда направиться, при этом не всегда предпочтение отдавалось церкви.

Законодательством Петра I вводилась ежегодная исповедь и причастие. Синод потребовал: 
«... 1716 февраля 8, 1718 февраля 17, 1721 февраля 10, 1722 июня 6, 1737 февраля 4 чисел указами повелено чтоб всякого звания и чина мужеска и женска пола людей от семи до самых престарелых лет повсягодно во святые посты у отцов своих духовных исповедались и святых тайн приобщались как живучи в домах своих, так и будучи от оных в отлучках. Буде же кто исповедываться и святых таин приобщаться повсягодно не будет, таковых ктоб какова звания и чина ни был губернаторам и воеводам, и другим светским командирам по подаваемым от духовных правительств от неисповедавшихся именным реэстрам взыскивать штрафы без упущения, а именно: с разночинцов и посадских за первой год - по рублю, за второй - по 2 рубля, за третий - по 3 рубля. А с поселян за первой по 5 копеек, за второй - по 10 коп., за третий - по 15 копеек...» (ГАИО, ф.276, оп.2, д.1, л.79).

Сам факт, что правительство возвращалось к данному вопросу более 5 раз, свидетельствует об особой важности данного вопроса.

Первоначально в списках неисповедавшихся отсутствовала четкая возрастная градация. Это приводило к большому числу неисповедавшихся, составлявших, в среднем, 10-12\% от общего числа прихожан. По данным за 1730 г. только в Иркутске и Иркутском уезде не были на исповеди 296 чел. Новая форма исповедальных росписей позволила более детализировать категорию «неисповедавшихся», разбив ее на составляющие: «неисповедавшихся по малолетству и старости» и «неисповедавшихся по нерачению». В среднем к концу XVIII в. в Иркутской епархии доля «неисповедавшихся по нерачению» в составе прихода составляла около $5 \%$.

Торжественные богослужения, объявляемые по различным случаям, также играли значительную роль в приходской жизни. Поводом к проведению подобных богослужений служили военные походы, важнейшие события в жизни царской семьи (вступление в брак, рождение наследника, восшествие на престол и т.п.), избавление от стихийных бедствий и др. Во время Северной войны регулярными стали молебствия о даровании победы. В одной из грамот времен Северной войны предписывалось:

«... по указу великого Государя велено о победе над неприятелем как прежь сего молебствовати во время его великого Государя походов, и так и ныне о том же всемогущего Бога молить, и для того послать во все епархии его великого государя указы; и как к тебе сей указ подан будет, освященным собором молебное пение отправлять по нововыходным прежним тетрадям, которые напечатаны вновь, и молить всемогущаго Бога о помощи православно-российскому воинству о победе над неприятелем...» (Древние церковные грамоты, 1875, cc. 172-173).

События в жизни царской семьи должны были в обязательном порядке отмечаться во всех приходах. В эти дни проводились особо торжественные богослужения. Так, 11 марта 1689 г. от тобольского митрополита поступила грамота о проведении богослужений по случаю бракосочетания царя Петра I с Евдокией Лопухиной. В 20-е гг. XVIII в. Синод упорядочил памятные и торжественные дни. Для этого была сформирована «Табель высокоторжественных и 
викториальных дней...». Она являлась руководящим документом, определявший не только сами торжественные дни, но и «какою церковною церемониею в священнослужениях отправлять надлежит» (Санников, 2018, с. 17).

Регламентировался и порядок проведения служб:

«В вышеписанные высокоторжественныя дни ... на всеношных бдениях быть и литургии и молебны отправлять как архиереям, так и монастырским настоятелям со освященным соборем: також и в церквах соборныя. А в приходских городских, сельских и слободских сколко при коей священников имеется, обще без отменения, кроме того, аще кто благословной коею виною воспрепятствован будет, сиесть болезнею или иной коею крайне недопущающею нуждою» (ГАИО, ф. 276, оп. 2, д. 1, л. 98).

Не ведение службы в такой день грозило приходскому духовенству наказанием. В 1733г. иркутский епископ Иннокентий (Нерунович) лишил сана и приговорил к наказанию кнутом и ссылке в Забайкалье илимского протопопа Ивана Петрова за то, что тот в день тезоименинства императрицы Анны Ивановны не служил всеношного бдения и литургии, предписанного «Табелью...» (ИЕВ, 1870, сс. 53-54).

\section{Выводы}

В целом церковная политика Петра I имела четкую направленность на установление контроля над процессом церковного строительства, сдерживание роста приходского духовенства, формализацию приходской жизни. Организатором этой политики стал Синод, а проводником выступал епископат.

Введенные правительством ограничения уже в первой половине XVIII в. привели к падению темпов церковного строительства в регионе. Только совместные действия местной гражданской и церковной администрации заставили власти пойти на уступки. Нормы по количеству дворов для Сибири удалось снизить, право принимать решение о постройке новой церкви и разрешать возведение деревянных церквей передавалось губернатору, при согласовании с епископом. Данные меры позволили активизировать процесс культового строительства в Восточной Сибири во второй половине XVIII в.

Социальный состав приходского духовенства также изменялся. Постоянно сокращалась доля выходцев из других сословий. Увеличилось число причтов, в составе которых находились родственники. Принцип комплектования причтов эволюционировал от выборности к наследственности и практике назначения. Однако, несмотря на явно прослеживающуюся тенденцию к замыканию приходского духовенства, достичь этого в Восточной Сибири полностью не удалось.

Основным фактором, определявшим развитие православного прихода в рассматриваемый период, стали взаимоотношения общины верующих и церковной администрации. До 20-х гг. XVIII в. преобладало влияние общины. 
Мирское самоуправление и выборное начало создавали условия для организации приходской жизни, опиравшиеся на материальные возможности общины. C 20-х гг. XVIII в. усилилось влияние церковной администрации. Верующие стремились сохранить свои традиции и обычаи, рассматривая церковь как инструмент, помогающий устроить свой быт. Государство, используя епископат, стремилось регламентировать приходскую организацию, снизить роль общины в церковных делах, формализовать формы религиозного общения. Это приводило к неизбежному снижению роли приходской общины и мирского самоуправления и вело к падению активности верующих, их инициативы и заинтересованности к делам прихода.

\section{Список литературы}

Государственный архив Иркутской области (ГАИО). (б. д.-а). Ф. 50. Оп. 1. Д. 3.

Государственный архив Иркутской области (ГАИО). (б. д.-b). Ф. 276. Оп. 2. Д. 1.

Древние церковные грамоты Восточно-Сибирского края. (1875). Казань.

Зольникова, Н. Д. (1977). Ставленнические дела как источник по социальным проблемам XVIII в. (По материалам Тобольской епархии). В Источниковедение и археография Сибири (сс. 14-40). Наука.

Зольникова, Н. Д. (1990). Сибирская приходская община в XVIII веке. Наука. Иркутские епархиальные ведомости. Прибавления. (ИЕВ). (1864). Иркутск. Иркутские епархиальные ведомости. Прибавления. (ИЕВ). (1868). Иркутск. Иркутские епархиальные ведомости. Прибавления. (ИЕВ). (1870). Иркутск. Иркутские епархиальные ведомости. Прибавления. (ИЕВ). (1880). Иркутск. Карташев, А. В. (1992). Очерки по истории русской церкви. В 2-х томах (Т. 2). Терра.

Наумова, О. Е. (1996). Иркутская епархия. XVIII - первая половина XIX века. Издательство Иркутского государственного технического университета.

Национальный архив Республики Татарстан (НАРТ). (б. д.). Ф. 10, Оn. 2, Д. 899.

Описание документов и дел, хранящихся в архиве Святейшего Правительствующего Синода: Т. 2. Часть 1. (1879). Санкт-Петербург.

Покровский, Н. Н. (1979). Исповедь алтайского крестьянина. В Памятники культуры: Новые открытия (сс. 49-57). Ленинград.

Полное собрание законов Российской илперии (ПСЗ-1) (Т. 4). (1830а). Санкт-Петербург.

Полное собрание законов Российской илперии (ПСЗ-1) (Т. 6). (1830b). Санкт-Петербург.

Полное собрание законов Российской илперии (ПСЗ-1) (Т. 7). (1830с). Санкт-Петербург.

Полное собрание законов Российской илперии (ПСЗ-1) (Т. 12). (1830d). Санкт-Петербург.

Полное собрание законов Российской илперии (ПСЗ-1) (Т. 14). (1830е). Санкт-Петербург.

Полное собрание законов Российской илперии (ПСЗ-1) (Т. 19). (1830f). Санкт-Петербург. 
Полное собрание постановлений и распоряжений по ведомству православного исповедания Российской илперии (ПСПиР) (Т. 3). (1875). Санкт-Петербург.

Полное собрание постановлений и распоряжений по ведомству православного исповедания Российской илперии (ПСПиР) (Т. 4). (1876). Санкт-Петербург.

Полное собрание постановлений и распоряжений по ведомству православного исповедания Российской илперии (ПСПиР) (Т. 5). (1881). Санкт-Петербург.

Посошков, И. Т. (1951). Книга о скудости и богатстве. Издательство Академии Наук СССР.

Санников, А. П. (2010). Из истории церковного управления в Восточной Сибири в XVIII в. В Материалы всероссийской научной конференщии, посвященной 200-летию со дня рождения генерал-губернатора Восточной Сибири Н.Н. Муравъева-Амурского (сс. 266-279). Восточно-Сибирская издательская компания.

Санников, А. П. (2016). Церковъ, общество и государство на восточных окраинах Российской uмnерии в XVII-XVIII веках. Издательство Иркутского государственного университета.

Санников, А. П. (2018). Официальные формы религиозного общения сибиряков в XVIII в. (По материалам Прибайкалья). В Забайкальские Рождественские образовательные чтения. Нравственные ценности и будущее человечества Материалы VII Научнопрактической конферениии [региональный этап Международных Рождественских образовательных чтений] (сс. 15-23). Забайкальский госусдарственный университет.

Шерстобоев, В. Н. (1957). Илимская пашня (Т. 2). Иркутское книжное издательство.

Щеглов, И. В. (1993). Хронологический перечень важнейших данных из истории Сибири: 1032-1882 г2. Северный дом.

\section{References}

Ancient ecclesiastical charters of the East Siberian region. (1875). Kazan. (In Russian).

Complete Collection of Laws of the Russian Empire (Vol. 4). (1830a). Saint Petersburg. (In Russian).

Complete Collection of Laws of the Russian Empire (Vol. 6). (1830b). Saint Petersburg. (In Russian).

Complete Collection of Laws of the Russian Empire (Vol. 7). (1830c). Saint Petersburg. (In Russian).

Complete Collection of Laws of the Russian Empire (Vol. 12). (1830d). Saint Petersburg. (In Russian).

Complete Collection of Laws of the Russian Empire (Vol. 14). (1830e). Saint Petersburg. (In Russian).

Complete Collection of Laws of the Russian Empire (Vol. 19). (1830f). Saint Petersburg. (In Russian).

Description of the Documents and Files of the Archives of the Holy Synod: Volume 2. Part 1. (1879).

Saint Petersburg. (In Russian).

Irkutsk Diocesan Gazette. Supplements. (1864). Irkutsk. (In Russian).

Irkutsk Diocesan Gazette. Supplements. (1868). Irkutsk. (In Russian).

Irkutsk Diocesan Gazette. Supplements. (1870). Irkutsk. (In Russian).

Irkutsk Diocesan Gazette. Supplements. (1880). Irkutsk. (In Russian).

Kartashev, A. V. (1992). Essays on the History of the Russian Church. In 2 volumes (Vol. 2). Terra. (In Russian).

National Archives of the Republic of Tatarstan (NART). (n. d.). F. 10, In. 2, C. 899. (In Russian).

Naumova, O. E. (1996). Irkutsk eparchy. 18th - first half of the 19th century. Publishing house of the Irkutsk State Technical University. (In Russian). 
Pokrovsky, N. N. (1979). Confession of an Altai peasant. In Cultural Monuments: New Discoveries (pp. 49-57). Leningrad. (In Russian).

Pososhkov, I. T. (1951). A book about scarcity and wealth. Publishing house of the USSR Academy of Sciences. (In Russian).

Sannikov, A. P. (2010). The history of ecclesiastical administration in Eastern Siberia in the 18th century. In Materials of the All-Russian Scientific Conference dedicated to the 200th anniversary of the birth of N.N. Muravyov-Amursky, Governor-General of Eastern Siberia (pp. 266-279). East Siberian Publishing Company. (In Russian).

Sannikov, A. P. (2016). Church, Society and State on the Eastern Margins of the Russian Empire in the 17th-18th centuries. Irkutsk State University Press. (In Russian).

Sannikov, A. P. (2018). Official Forms of Religious Communication of Siberians in the 18th Century. (On the Materials of the Baikal Region). In Transbaikalia Christmas Educational Readings. Moral Values and the Future of Mankind Materials of the VII Scientific-Practical Conference [Regional stage of the International Christmas Educational Readings] (pp. 15-23). Transbaikal State University. (In Russian).

Shcheglov, I. V. (1993). A chronological list of the most important data from the history of Siberia: 1032-1882. Northern House. (In Russian).

Sherstoboev, V. N. (1957). Ilimskaya arable land (Vol. 2). Irkutsk Book Publishers. (In Russian).

State Archives of the Irkutsk Region (SAIR). (б. д.-а). F.50. In.1. C.3. (In Russian).

State Archives of the Irkutsk Region (SAIR). (n. d.-b). F.276. In.2. C.1. (In Russian).

The Complete Collection of Ordinances and Directives of the Orthodox Confession in the Russian Empire (Vol. 3). (1875). Saint Petersburg. (In Russian).

The Complete Collection of Ordinances and Directives of the Orthodox Confession in the Russian Empire (Vol. 4). (1876). Saint Petersburg. (In Russian).

The Complete Collection of Ordinances and Directives of the Orthodox Confession in the Russian Empire (Vol. 5). (1881). Saint Petersburg. (In Russian).

Zolnikova, N. D. (1977). Vocations as a source on social problems of the 18th century. (Based on materials of the Tobolsk diocese). In Source studies and archaeography of Siberia (pp. 14-40). Nauka. (In Russian).

Zolnikova, N. D. (1990). The Siberian parish community in the 18th century. Nauka. (In Russian). 